Ann. Génét. Sél. anim., I974, 6 (2), 227-239.

\title{
SELECTION IN DUAL-PURPOSE CATTLE POPULATIONS : EFFECT OF BEEF CROSSING AND COW REPLACEMENT RATES
}

\author{
E. P. CUNNINGHAM and A. E. McClINTOCK (1) \\ The Agricultural Institute, \\ Dunsinea, Castleknock, Co. Dublin (Ireland)
}

\section{SUMMARY}

The discounted gene-flow method is used to calculate the effects of varying cow replacement and beef crossing rates on the breeding policy appropriate for a dual-purpose cattle population. It is shown that increasing beef crossing and increasing cow replacement rates both increase the number of expressions of a bull's dairy genotype following one insemination while the expressions of his beef genotype are little affected. The result of this is that (I) a high level of beef crossing is efficient, (2) more emphasis should be given to dairy traits in selecting bulls, (3) the return for investment in dairy bull testing and selection is enhanced.

\section{INTRODUCTION}

Dual purpose bulls for use in AI should be selected for a weighted function of their additive genetic merit for the dairy and beef traits of interest in the population concerned. In a previous paper (MCCLINTOCK and CUNNINGHAM, I97I) it was shown that the selection objective can be defined to reflect the real economic value of the bull's total genotype as expressed through one insemination. This requires that each beef or dairy trait be weighted by a factor which is the product of two elements :

a) the financial value of a unit of production for the trait;

b) the number of standardised expressions of the bull's genotype for the trait, which will follow from one insemination.

The financial element depends on production costs and market returns. In any particular population, it will be relatively fixed. The relative degrees of expression

(1) Present Address : Milk Marketing Board, Thames Ditton, Surrey, England. 
of the bull's beef and dairy genotype depend primarily on the probability that the calf born from an average insemination will become a dairy cow. This probabiliy in turn depends on two aspects of population structure : the amount of crossing with beef bulls and the replacement rate of dairy cows. In this paper, we examine the way in which these factors affect the definition of the breeding objective, and through it the whole breeding strategy in dual purpose cattle populations.

\section{METHODS}

We define as "dual-purpose " any population in which the cows are milked and the male and surplus female progeny are reared for beef. Population size is presumed constant. All calves are reared either as cow replacement or as beef animals for sale at about two years of age. Heifers calve at two years of age, and 85 progeny are reared per hundred cows per year. All cows are bred artificially either to selected dual purpose bulls of their own breed, or to bulls of a specialised beef breed. Dual-purpose bull selection is based on an index which is calculated assuming heritabilities of 0.2 for milk yield and 0.3 for growth rate. Progeny group sizes are to for beef progeny and 40 for dairy progeny. The genetic correlation of milk yield and growth was given values of $-0.2,0.0$ and 0.2 , though the main results are presented only for the zero correlation. Selection procedures for beef breed bulls are not considered, but it is assumed that $(a)$ the cost per bull is not greater than that for a dual purpose bull, and (b) that the progeny of beef breed bulls are at least as good for beef production as those of dual-purpose bulls.

Since the main components of dairy and beef merit are milk yield and growth rate, we assumed that bulls are selected solely on these traits. Selection is on a conventional index which incorporates up to $\mathrm{I} 5$ items of information, ranging from a beef performance test on the bull's grandsire to a dairy progeny test on his daughters (table I). The objective is to select those bulls which excel for a total genotype defined as

$$
\mathrm{T}=v \mathrm{~B}+w \mathrm{D}
$$

where $\mathrm{B}$ and $\mathrm{D}$ are the bull's genotypes for growth rate and milk yield, and $v$ and $w$ are relative net economic weights.

As shown by McClintock and Cunningham (1973) the appropriate economic weights are

$$
v=\mathrm{E}_{b} \mathrm{C}_{b} \quad \text { and } \quad w=\mathrm{E}_{d} \mathrm{C}_{d}
$$

where $\mathrm{E}_{b}$ and $\mathrm{E}_{a}$ are the numbers of standard discounted expressions of the bull's beef and dairy genotypes following one insemination, and $\mathrm{C}_{b}$ and $\mathrm{C}_{d}$ are the financial values of a unit increase in beef and milk production. In our calculations, we have taken the phenotypic standard deviation for each trait as the unit of measurement. Our financial values $C_{b}$ and $C_{d}$, are therefore per standard deviation for beef $\left(\sigma_{b}\right)$ and milk $\left(\sigma_{d}\right)$ respectively. If the net financial returns per $\mathrm{kg}$ of beef $\left(i . e\right.$. per $\mathrm{kg}$ liveweight at a fixed age) and milk are $\mathrm{F}_{b}$ and $\mathrm{F}_{d}$, then

$$
\mathrm{C}_{b}=\mathrm{F}_{b} \sigma_{b} \quad \text { and } \quad \mathrm{C}_{d}=\mathrm{F}_{d} \sigma_{d} .
$$

Since only two traits are involved, it is convenient to take the economic weight for beef as unity, and that for milk as

$$
\frac{w}{v}=\frac{\mathrm{E}_{d}}{\mathrm{E}_{b}} \frac{\mathrm{C}_{d}}{\mathrm{C}_{b}}=\frac{\mathrm{E}_{d}}{\mathrm{E}_{b}} \frac{\mathrm{F}_{d}}{\mathrm{~F}_{b}} \frac{\sigma_{d}}{\sigma_{d}}
$$

Thus, the relative economic weights for the two traits can be treated as the product of three separate ratios. The ratio $\sigma_{d} / \sigma_{b}$ depends on the scale of milk and beef production per animal. We have assumed that all beef animals are reared to about two years of age, or about $500 \mathrm{~kg}$ liveweight. Growth rate has a coefficient of variation of about Io p. Ioo, so that this implies a value of $\sigma_{b}=50 \mathrm{~kg}$ approximately. Milk yield has a coefficient of variation of about $20 \mathrm{p}$. Ioo. Average production per lactation varies in European countries from 2500 to $5000 \mathrm{~kg}$, giving a range of $\sigma_{d}$ from 500 to I ooo $\mathrm{kg}$. The ratio $\sigma_{d} / \sigma_{b}$ can therefore vary from about Io to 20 , depending on the scale of milk production per cow. In any particular population the ratio will be fairly constant, and in these calculations we have taken a value relevant to Irish conditions of 12.5 We discuss later the possible effect of variation in this ratio. 
TABLE I

Items of information included in bull selection index

Différents postes pris en considération pour le calcul de l'index des taureaux

\begin{tabular}{|c|c|}
\hline $\begin{array}{l}\text { Source of information } \\
\text { Origine de l'information }\end{array}$ & $\begin{array}{l}\text { Number of records } \\
\text { Nombre } \\
\text { de performances }\end{array}$ \\
\hline $\begin{array}{l}\text { Dairy traits } \\
\text { Caracteres laitiers }\end{array}$ & \\
\hline $\begin{array}{l}\text { 1. Bull's own progeny } \\
\text { Descendance du taureau }\end{array}$ & 40 \\
\hline $\begin{array}{l}\text { 2. Bull's dam } \\
\text { Mère du taureau }\end{array}$ & 2 \\
\hline $\begin{array}{l}\text { 3. Bull's paternal granddam } \\
\text { Grand-mère paternelle du taureau }\end{array}$ & 2 \\
\hline $\begin{array}{l}\text { 4. Bull's maternal granddam } \\
\text { Grand-mère maternelle du taureau }\end{array}$ & 2 \\
\hline $\begin{array}{l}\text { 5. Bull's paternal half sibs } \\
\text { Demi-scurs paternelles du taureau }\end{array}$ & 40 \\
\hline $\begin{array}{l}\text { 6. Progeny of paternal grandsire } \\
\text { Descendance } d u \text { grand-père paternel }\end{array}$ & 40 \\
\hline $\begin{array}{l}\text { 7. Progeny of maternal grandsire } \\
\text { Descendance du grand-père maternel }\end{array}$ & 40 \\
\hline $\begin{array}{l}\text { 8. Half sibs of paternal grandsire } \\
\text { Demi-soeurs du grand-pere paternel }\end{array}$ & 40 \\
\hline $\begin{array}{l}\text { 9. Half sibs of maternal grandsire } \\
\text { Demi-sceurs du grand-père maternel }\end{array}$ & 40 \\
\hline $\begin{array}{c}\text { Beef traits } \\
\text { Caractères de Production de viande }\end{array}$ & \\
\hline $\begin{array}{l}\text { 10. Bull's own performance } \\
\text { Performance individuelle du taureau }\end{array}$ & 1 \\
\hline $\begin{array}{l}\text { 11. Bull's own progeny } \\
\text { Descendance du taureau }\end{array}$ & 10 \\
\hline $\begin{array}{l}\text { 12. Bull's sire } \\
\text { Père du taureau }\end{array}$ & 1 \\
\hline $\begin{array}{l}\text { 13. Bull's paternal grandsire } \\
\text { Grand-père paternel du taureau }\end{array}$ & 1 \\
\hline $\begin{array}{l}\text { 14. Bull's maternal grandsire } \\
\text { Grand-père maternel du taureau }\end{array}$ & 1 \\
\hline $\begin{array}{l}\text { 15. Bull's paternal halfsibs } \\
\text { Demi-frères paternels du taureau }\end{array}$ & 10 \\
\hline
\end{tabular}


The value of the financial returns on beef $\left(\mathrm{F}_{b}\right)$ and milk $\left(\mathrm{F}_{d}\right)$ are best expressed as the cash return over feed cost for each additional $\mathrm{kg}$ of liveweight or milk yield. Costs other than feed are per animal or per lactation, and not per unit of production. In Irish conditions, the ratio of net returns for beef and milk is about 6 , that is to say that the net return on I $\mathrm{kg}$ of liveweight $\left(F_{b}\right)$ equals the net return $\left(F_{d}\right)$ on six $\mathrm{kg}$ of milk. Irish feed costs for milk production are exceptionally low by European standards. The value of $\mathrm{I} / 6$ is therefore likely to be at the lower end of the range of values which the ratio $\mathrm{F}_{d} / \mathrm{F}_{b}$ will have in European countries. In our present calculations, we have used a value of $\mathrm{F}_{d} / \mathrm{F}_{b}=\mathrm{I} / 7$. The effect of variation in this ratio is discussed below.

In any particular population, therefore, the ratio of net economic weights for dairy and beef traits will depend mainly on the ratio $\mathrm{E}_{d} / \mathrm{E}_{b}$. The genetic consequences of a single insemination are summarised in the factors $\mathrm{E}_{b}$ and $\mathrm{E}_{a}$. The standard unit in which they are calculated is defined to be one progeny expression of the trait in the year in which the insemination is carried out. All future expressions are adjusted for the generation in which they occur, discounted for the time interval separating them from the insemination, and weighted by the probability of their occurrence. $\mathbf{E}_{\boldsymbol{b}}$ and $\mathbf{E}_{\boldsymbol{d}}$ represent the sum of these discounted consequences of the insemination for beef and dairy traits respectively. We have called this series of adjustments the "Discounted Gene Flow Method *, and its derivation is described in more detail elsewhere (MCCLINTOCK and CUNNINGHAM, 1973).

The probabilities involved are functions of the following three parameters of population structure :

$\mathrm{L}:$ the average number of lactations per cow ;

$\mathrm{K}$ : the proportion of cows crossed to beef bulls;

$S$ : the number of animals surviving to maturity per successful insemination.

The probability that the insemination leads to a lactation by a descendant in generation $g$ is then $\mathrm{L}^{g}(\mathrm{I}-\mathrm{K})^{-1}$. The probability of a beef progeny is $(\mathrm{SL}(\mathrm{I}-\mathrm{K})-\mathrm{I}) / \mathrm{L}(\mathrm{I}-\mathrm{K})$, and the probability of a beef descendant in a later generation is (SL - I)/Lg(I-K). If $r$ is the discount rate in percentage units and $\mathbf{N}_{\boldsymbol{d g} \boldsymbol{y}}$ is the number of possible dairy descendants in generation $g$ and year $y$, then the total discounted dairy progeny equivalents from one insemination is

$$
\mathbf{E}_{\boldsymbol{d}}=\sum_{g=1}^{\mathbf{G}} \sum_{y=0}^{\mathrm{Y}} \mathbf{N}_{d g y}\left(\frac{\mathrm{I}}{2}\right)^{g-1}\left[\frac{\mathrm{IOO}}{\mathrm{IOO}+r}\right]^{y} \frac{\mathrm{I}}{\mathrm{L}^{g}(\mathrm{I}-\mathrm{K})}
$$

where $G$ and $Y$ are the number of generations and years considered. Similarly, the number of discounted beef progeny equivalents is

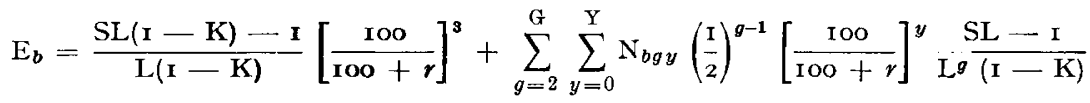

Note that in this case we separate the actual beef progeny, which can occur in year three, from the other beef descendants which arise via a dairy daughter. The summation over generations therefore begins at $g=\mathbf{2}$.

The calculation and evaluation of the selection indexes involved was carried out using the general index program Selind (CunNINGHAM, 1970).

\section{RESULTS}

\section{I. - General}

The object of this study is to clarify the effect of varying beef crossing and cow turnover rates on the breeding strategy for dual-purpose cattle. These factors enter into $\mathrm{E}_{b}$ and $\mathrm{E}_{d}$, and therefore into the net economic weights which should be used to define the balance of beef and dairy traits in the breeding objective. In order to trace the effects of beef crossing and cow turnover rates, it is therefore necessary to fix as far as possible the other factors involved. We have taken a value of I2.5 for the ration $\sigma_{d} / \sigma_{b}$ and $\mathrm{I} / 7$ for the ratio $\mathrm{F} / d \mathrm{~F}_{b}$. 
The ratio of the dairy and beef genetic consequences of an insemination, $\mathrm{E}_{d} / \mathrm{E}_{b}$, is quite complex. However, many of the factors involved can be taken as fixed. The survival rate per successful insemination will be fairly constant in any particular population, and we have taken $\mathrm{S}=0.85$. The discount rate has been taken as $r=8 \mathrm{p}$. Ioo.

We have fixed $\mathrm{Y}$ at Io years. This is reasonable in the operational sense that the economic gain from a particular insemination in the ro hears following that insemination is likely to satisfy both the users of A. I. and the A. I. authorities who must evaluate the investment in bull testing and selection. In addition, genetic predictions over many gentations tend to be uncertain, and ro years involve four generations of descendants of the bull. However, we should also check whether the effect of the insemination in question is largely compelte within the Io years, or whether it is still in a stage of rapid development.

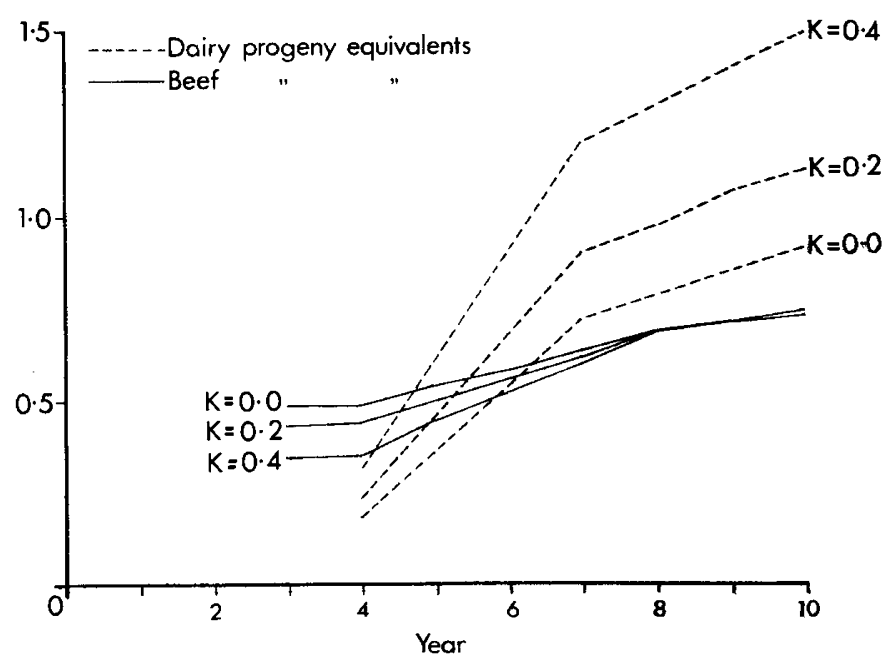

FIG. I. - Cumulative numbers of discounted beef and dairy progeny equivalents following one insemination in year o

Four lactations per cow and 85 p. roo net reproduction are assumed

FIG. I. - Nombres actualisés cumulés de performances laitières et bouchères équivalentes des descendants d'une insémination réalisée l'année initiale

(en admettant 4 lactations par vache et un taux de reproduction de 85 p. roo)

In figure I we have plotted the cumulative numbers of beef and dairy expressions for Io years following one insemination for a population with 4 lactations per cow, and for crossbreeding values of $\mathrm{K}=0.20$ and $40 \mathrm{p}$. Ioo. It can be seen that the number of beef expressions $\left(\mathrm{E}_{b}\right)$ increases little after the first few years. The number of dairy expressions is still increasing at year Io, though at a declining rate. We are therefore justified in limiting consideration to the ro years following the insemination. If we chose to include additional years, the effect would always be to increase the ratio of dairy to beef expressions. The pattern of cumulative discounted consequences of an insemination is similar for populations with 3,5 and 6 lactations per cow. 


\section{2. -- Effect of population structure}

The way in which the actual numbers of standard discounted beef and dairy expressions vary with varying beef crossing $(\mathrm{K})$ and cow turnover $(\mathrm{L})$ rates is shown in figure 2. The number of beef expressions is essentially the same whatever the level of crossbreeding. The reason for this is that a large proportion of the net discounted beef expressions comes from an actual beef progeny. As $\mathrm{K}$ increase, a larger proportion of heifer calves per dairy insemination are required as herd replacements, and the probability that such an insemination leads directly to a beef progeny is therefore reduced. However, since the probability that the insemination leads to a replacement female is simultaneously increased, the probability of beef expressions in later generations via the female, is also increased, which offsets the corresponding reduced probability of a progeny beef expression. The result is that the total number of discounted beef expressions is relatively stable, whatever the breeding structure of the population.

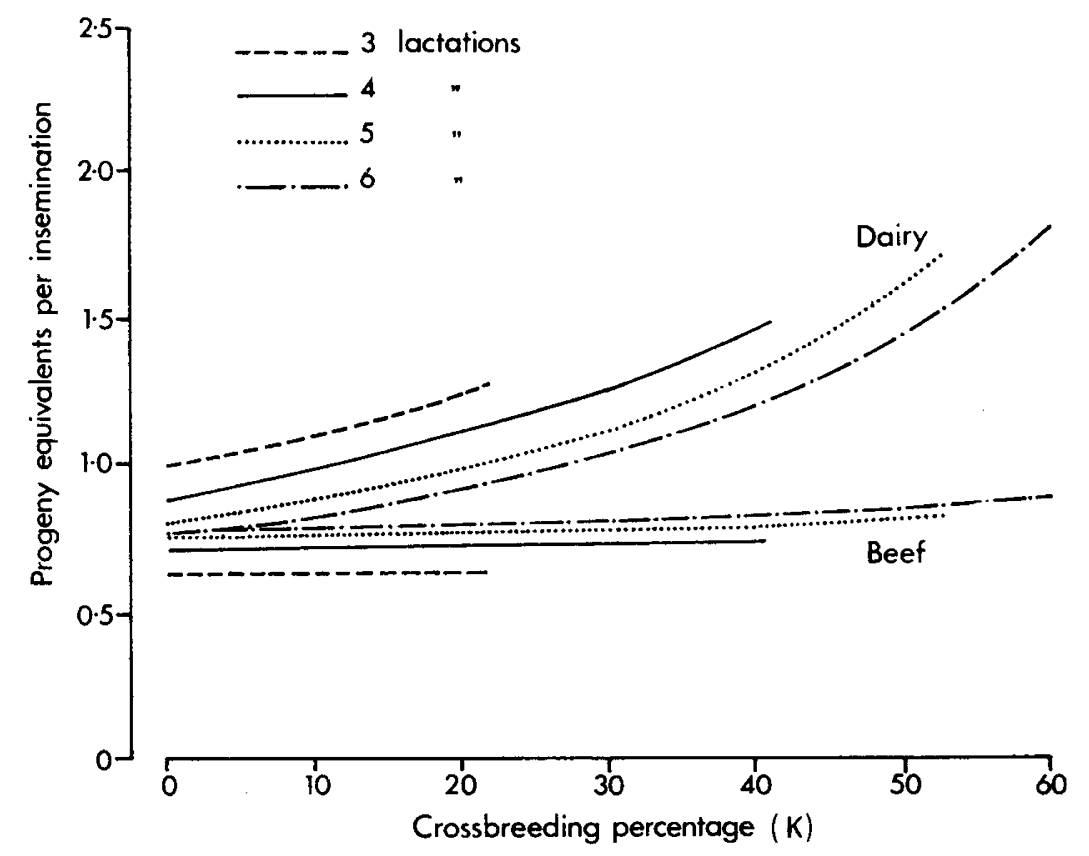

FIG. 2. - Discounted dairy and beef progeny equivalents for varying lactations per cow and percent beef crossing

FIG. 2. - Nombres actualisés de performances laitières et bouchères équivalentes des descendants pour des nombres variables de lactations par vache et pour différents taux de croisement avec des taureaux à viande

In contrast, the number of dairy expressions incrases steadily as $\mathrm{K}$ increases. The result is that the ratio $\mathrm{E}_{d} / \mathrm{E}_{b}$ also increases nearly linearly with $\mathrm{K}$. The effect of increasing $\mathrm{K}$ is therefore to increase the weighting on milk relative to beef in the selection objective. This has widespread consequences for the breeding pro- 
gramme: it increases the emphasis on milk in bull selection, increases the total return on investment in testing, and increases the proportion of this return which comes via milk.

The effect of increasing the rate of cow turnover is similar to, though less marked than the effect of increasing beef crossing. The fewer lactations per cow, the greater the proportion of heifer calves required for herd replacement, and the greater the probability that a dairy insemination will result in a replacement female.

For a population of constant size, the limits to beef crossing are dictated by the rate of cow turnover, and by the net reproductive performance of the population.

TABLE 2

Maximum percentages of beef crossing as affected by population reproductive rate (S) and number of lactations per cow (L)

Taux maximum de croisement avec des taureaux à viande permis compte tenu du taux de reproduction (S) de la population et du nombre de lactations par vache (L)

\begin{tabular}{c|c|c|c}
\hline $\begin{array}{c}\text { Lactations/Cow } \\
\text { Nombre de lactations } \\
\text { par vache }\end{array}$ & \multicolumn{2}{|c}{$\begin{array}{c}\text { Population Reproductive Rate } \\
\text { Taux de reproduction de la population }\end{array}$} \\
\hline & 0.80 & 0.85 & 0.90 \\
\hline 3 & 16.7 & 21.6 & 26.0 \\
4 & 37.5 & 41.2 & 44.5 \\
5 & 50.0 & 52.9 & 55.6 \\
6 & 58.3 & 60.8 & 63.0 \\
\hline \hline
\end{tabular}

These maximum levels of $\mathrm{K}$ are given in table 2 . The actual numbers of discounted beef and dairy progeny equivalents per insemination for the full range of beef crossing and cow replacement rates which are feasible in practice is given in table 3 .

The ratios of $E_{d} / E_{b}$ for varying beef crossing and cow replacement rates are also given in table 3. Since we have for the moment considered the ratio of phenotypic standard deviations fixed at $\mathrm{r} 2.5$ and the ratio of economic values fixed at $\mathbf{r} / 7$, the ratio of net economic weights to use in selecting bulls, $w / v$, is a direct function of $\mathrm{E}_{d} / \mathrm{E}_{b}$. This is shown in table 3 .

Once the breeding objective has been defined in this way, it is possible to calculate the economic effectiveness of a programme of bull selection using a given array of information. The measure of effectiveness is the economic value of the genetic merit conferred on the population by a single insemination. This is

$$
\frac{\mathrm{I}}{2} \bar{\imath} \sigma_{\mathrm{I}}
$$

where $\bar{i}$ is the selection differential on a standard normal distribution and $\sigma_{\mathrm{I}}$ is the standard deviation of the index used for bull selection. Provided the same selection differential is applied in all cases, the relative gains from selection are then simply the relative standard deviations of the index. For convenience, we have given the 


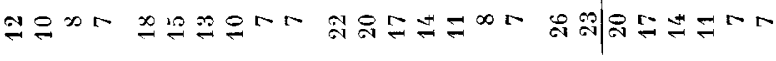

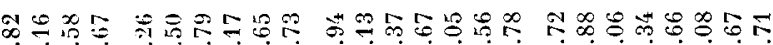

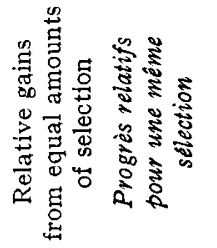

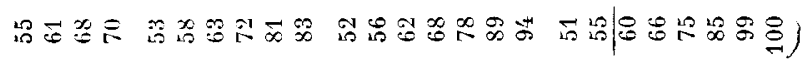

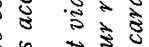

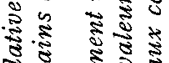

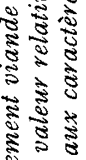

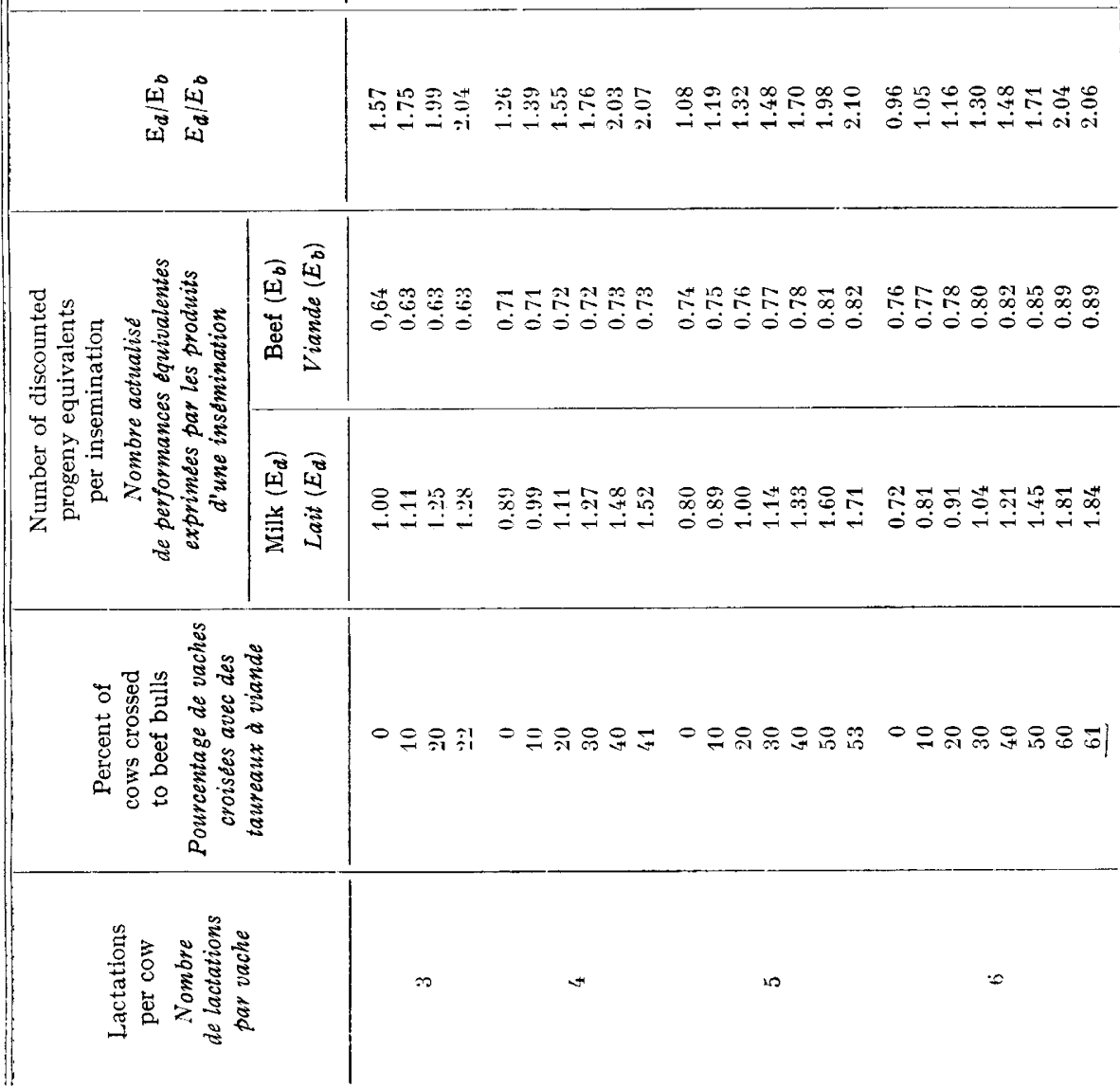


gain for the most effective situation a value of Ioo and scaled the others down from that. In table 3 , the relative economic value of an insemination is given for each combination of $\mathrm{K}$ and $\mathrm{L}$. Note that since the same information is used and the same level of selection applied in each case, these figures represent the relative economic returns for a constant level of investment in testing and selection.

Whatever economic gain is conferred with each insemination is composed of gain due to genetic improvement for milk yield and gain due to improvement of growth rate. It is of some interest to know what proportion of the total gain is attributable to improvement in each trait. In table 3 we have shown the percentage of total economic gain which is due to improved growth rate for each combination of number of lactations and degree of croossbreeding. The method for calculating these percentages is given by CunNingham (I970).

There is some uncertainty about the genetic relationship between milk and beef traits in dual-purpose cattle populations (MAson et al., I97I). We therefore gave the genetic correlation of milk yield and growth rate values of -0.2 and +0.2 , and recalculated the relative genetic return per insemination for each of these situations. The result was, as might be expected, that the net gain was slightly less for the negative and slightly more for the positive correlation. The change in each case was about 2.5 p. Ioo. A negative correlation also slightly increases the share of total economic gain from selection which is due to improvement in milk yield. However, the effects of variation in crossbreeding percent and cow turnover rates were barely affected, and the general conclusions regarding population structure therefore hold for this range of genetic relationships between milk and beef.

\section{DISCUSSION}

In order to develop the results given here, we have had to relate the calculations to a particular population, to the extent of fixing the ratio of standard deviations and the ratio of financial margins for milk and beef production. (Their product is in fact the ratio of the net value of one phenotypic standard deviation in milk yield to the net value of one phenotypic standard deviation in liveweight). In our case, it was I.8.

However, this ratio is not likely to differ greatly in other populations. As GRAVERT (I966) has shown, the ratio of gross returns for I $\mathrm{kg}$ milk and $\mathrm{r} \mathrm{kg}$ liveweight in European countries covers a relatively narrow range of $\mathrm{I}: 5.3$ to I : 8.I. The standard deviation for liveweight that we have used should be fairly generally applicable. That for milk is low for many countries. However, as the yield per cow increases, and with it the standard deviation in yield, the feed cost per unit of production is also likely to increase, thus reducing the margin over feed cost. So any increase in $\sigma_{d}$ will tend to be offset by a reduction in $F_{d}$, thus stabilising the product of the two ratios.

The only result which can be affected by this factor is the ratio of economic weights in the selection objective, and through it the percentage of total gain which becomes via improvement in milk and beef (table 3 ). The relative economic return per insemination for different population structures (table 3) is essentially inde- 
pendent of change (particularly upward change) in the product $\frac{\mathrm{F}_{d}}{\overline{\mathrm{F}_{b}}} \frac{\sigma_{d}}{\sigma_{b}}$. All the other results are quite independant of it. The general conclusions which we draw from these results should therefore be applicable over a wide range of situations.

The higher the cow replacement rate $(i . e$. the fewer lactations per cow), and the higher the percentage of cows bred to beef bulls, the greater will be the probability that a dual-purpose insemination will result in a dairy animal. This probability is the key to the other results. As it increases, so does the probability of dairy descendants in later generations. The result is that the number of discounted dairy progeny equivalents per insemination increases rapidly. However, the probability of an initial dairy progeny has little effect on the discounted beef progeny equivalents per insemination. The reason for this is that the beef consequences of the insemination are expressed either in an immediate progeny or through the beef descendants in later generations which arise via a dairy daughter. The probabilities of these two outcomes are complementary : as one goes up the other must come down. The result is that irrespective of the probability of the initial insemination leading to a dairy daughter, the total effect in terms of discounted beef progeny equivalents is relatively static.

As beef crossing $(\mathrm{K})$ increases, a higher proportion of the heifer calves resulting from dairy inseminations will be required for herd replacement. Thus the probability of a dairy insemination leading to a lactating daughter is increased. The result is that the ratio of expressions moves very much in favour of dairy traits. This has a parallel effect on the ratio of economic weights for dairy and beef traits in the selection objective. We therefore find that both the ratio of expressions and ratio of economic weights increase rapidly as beef crossing increases and more slowly as the number of lactations per cow goes down (fig. 2 and table 3 ). Note that while the absolute number of beef and dairy expressions depends on the rate of cow turnover, their ratio is, within rounding errors, the same for all levels of cow turnover provided beef crossing is at its maximum.

As the balance of economic weights moves in favour of milk, the total financial return per insemination increases fairly rapidly. The reason for this is basically that the economic value of the increased number of dairy expressions is being added to the nearly constant economic return from the beef expressions. In table 3, the relative returns per insemination are given by number of lactations per cow and by proportion of crossbreeding. Since in these calculations we have assumed that the information used and cost incurred for each bull selected is the same for all situations, those conditions which increase the return per insemination also increase the total return on the investment in bull testing and selection.

One effect of changes in the relative economic weights in the breading objective will be to alter the value of the different items of information (table I) that can be used in selecting dual purpose bulls. As the ratio of economic weights shifts in favour of milk, the value of data on the growth rate of the bull and his relatives declines, while dairy records increase in value. The lowest relative economic weights that we have encountered are $w / v=\mathrm{I} .72$ (no beef crossing and six lactations per cow). The most valuable item of information in bull selection here is his dairy progeny test - net genetic gain is reduced by $\mathrm{R}=33 \mathrm{p}$. IoJ if this is ignored. The next most valuable item is his beef progeny test ( $R=$ Io $p$. roo), followed by his bəef 
performance test ( $R=2 \mathrm{p}$. IOO). As the ratio of economic weights moves to its maximum value of $w / v=3.78$ (maximum beef crossing, 5 lactations per cow), the utility of these items changes considerably : the dairy progeny test is now of overwhelming importance $(R=4 \mathrm{I}$. IOo), while the beef progeny $(R=2 \mathrm{p}$. IOo) and performance $(\mathrm{R}=0.5 \mathrm{p}$. IOO) tests contribute little to total gain. It is therefore evident that the population structure, and in particular the amount of beef crossing, has a great deal to do with the kind of testing programme that is appropriate.

The cow turnover rate depends mainly on the intensity of milk production. and would be very difficult to alter. The proportion of cows bred to beef bulls, however, can easily be modified from one year to another. The proportion of beef crossing in current practice ranges from $50 \mathrm{p}$. Ioo in Ireland (CuNNINGHAM et al., I97I) to 38 p. IOo in Britain (MILK MARKETING BoARD, I970), 27 p. IOo in France (FREBLING et GAILIARD, I969) and practically zero in the Scandinavian countries (LINDSTRÖM, I970). Our results suggest that the most efficient dual-purpose breeding programme requires the maximum amount of beef crossing that the population can tolerate.

This conclusion is reinforced by some quite separate advantages that follow from a certain amount of beef crossing. If a farmer must request a beef or a dual-purpose insemination for each cow, he is likely to select his best cows for dualpurpose inseminations. This compels him to a greater degree of selection in the dams of his replacement heifers than would otherwise be the case. In countries with a distinct commercial beef cow population $(30 \mathrm{p}$. Ioo of all cows in Ireland and in Britain), the use of beef breed bulls on the dual-purpose cows in dairy herds provides a steady supply of beef $\times$ dual-purpose heifers as replacement cows for the beef herds. These should have three advantages over heifers bred within the beef herd : lower cost, higher milk yield and more heterosis for reproductive and maternal ability. Finally, if even partial control of the sex ratio becomes practicable in A. I. the advantages of beef crossing on the dairy cow population will be increased even further.

In the final column of table 3 , the percent of total return per insemination due to genetic improvement in growth rate is shown. If cow turnover rate is fast $i . e$. 3 lactations per cow, beef never accounts for more than about ro p. Ioo of the total gain. With a longer cow life, it can contribute up to $24 \mathrm{p}$. Ioo of the gain. However, its contribution rapidly drops off as the beef crossing percentage increases. The general conclusion is that either a fast rate of cow turnover, or a high level of beef crossing increases the probability that an insemination will lead to a dairy animal, that this gives dairy traits a high value in the selection objective, and that as a result, the total return from that insemination, and the proportion of that return due to milk improvement is greatly increased. This chain of cause and effect is shown in figure 3 .

\section{CONCLUSIONS}

I. The most efficient breeding programme for milk and beef in a dual-purpose population will require the maximum amount of crossing with beef breed bulls that is compatible with the provision of cow replacements. 
2. If all other factors are constant, the effect of increasing the level of crossbreeding by I p. Ioo is to increase the economic value of the genetic merit conferred with each dual-purpose insemination by approximately I $\mathrm{p}$. Ioo. This effect is greatest where an appreciable amount of crossbreeding is already being practised.

3. A second effect of increasing the percentage of cows bred to beef bulls is to greatly increase the emphasis which should be given to milk production in the selection of dual-purpose bulls.

4. The percentage of total economic gain from dual-purpose bull selection which is accounted for by improvement of milk yield varies from $75 \mathrm{p}$. Ioo to nearly Ioo p. IOO. If $20 \mathrm{p}$. IOo or more of the cows are bred to beef bulls, the percentage is always over 80 p. roo.

5. A high cow replacement rate has an effect similar to a high level of beef crossing, i. e., it increases the emphasis on and return via milk.

6. The effects of level of crossbreeding and cow replacement rate on both the total gain from selection, and on the balance of gain via milk and beef, comes for the most part through their effects on the number of expressions "of a bull's genotype for milk and beef.

7. A high level of beef crossing and/or a high cow replacement rate greatly enhances the return on investment in the testing and selection of dual-purpose bulls.

Rę̧u pour publication en février 1974 .

\title{
RÉSUMÉ
}

\author{
EFFE'T DU CROISEMENT AVEC UNE RACE A VIANDE \\ ET DU TAUX DE RENOUVELLEMENT DES VACHES \\ SUR LA SÉLLECTION DES BOVINS DE RACE MIXTE
}

On a utilisé la méthode d'estimation de la diffusion des gènes avec actualisation pour calculer l'incidence du taux variable de renouvellement des vaches et du croisement industriel sur la méthode de sélection à appliquer dans une population bovine de race mixte. On a montré qu'accroître le niveau du croisement industriel et le taux de renouvellement amène dans les deux cas le génotype laitier du taureau à s'exprimer plus souvent pour une insémination donnée alors que cela a peu d'effet sur l'expression du génotype boucher. Le nombre d'expressions du génotype boucher est peu affecté. Dans ces conditions, (I) un haut niveau de croisement industriel est efficace, (2) on doit donner plus d'importance aux caractères laitiers pour le choix des taureaux, (3) la rentabilité des investissements consacrés au testage et à la sélection des taureaux est améliorée.

\section{REFERENCES}

Cunningham E. P., Broderick T., x 969 . Genetic and environmental parameters of growth and carcass traits in dual-purpose cattle. Ir. J. A gric. Res., 8, 397-4r6.

Cunningham E. P., I97o. Selind, a fortran computer program for genetic selection indexes. Stencil report, Agric., Inst., Dublin.

Cunningham E. P. The relative efficiencies of selection indexes. Acta Agric. Scand. 19, 45-48.

Cunningham E. P., Mescal A. A., Looby M., I97I. Breeding better beef cattle. Proceedings of Beef in the Seventies. Conference, Dublin. 
Frebling J., Gaillard J., i97o. Efficacité du schéma de sélection des mâles de races à viande françaises en vue de leur utilisation en croisement industriel. Bull. tech. Dep. Génét. anim. (I. N. R. A., Fr.) 8.

Gravert H. O., 1966. Selection for milk, butterfat and beef production in European Friesians. Proc. 9th Int. Congress of Animal Production, Edinburgh, 314-324.

Lindström U., r97o. Breeding and crossbreeding for beef production in Finland. Z. Tierz. Züchtgsbiol. 87, 312-324.

Mason I. L., Vial V. E., Thompson R., I97i. Genetic parameters of beef characters and the genetic relationship between meat and milk production in British Friesian cattle. Animal Production, 14, I35-I 48 .

McClintock A. E., Cunningham E. P., r97i. Selection in dual-purpose cattle populations : defining the selection objective. Animal Production (in press).

MILK MARKETING BOARD, 1970. Report of the breeding and production organisation 20. Thames Ditton. Surrey. England. 